Brit. J. industr. Med., 1965, 22, 230.

\title{
POISONING BY META-ISOSYSTOX IN SPRAYMEN AND IN ACCIDENTALLY EXPOSED PATIENTS
}

\author{
BY \\ M. R. HEGAZY \\ From the Drugs Control Section, Public Health Laboratories, \\ Agouza, Cairo, U.A.R.
}

(RECEIVED FOR PUBLICATION OCTOBER 13, 1964)

\begin{abstract}
One hundred and twenty-six patients poisoned by the organic phosphorus insecticide Metaisosystox were investigated. Hiccough and extrapyramidal manifestations were noticed in some patients. Serum cholinesterase levels showed an initial fall and then a rise above normal. The fall of cholinesterase was marked in patients who were exposed for relatively long periods but not in patients accidentally exposed for short times. The rise in serum cholinesterase is thought to be a compensatory protective mechanism.

Correlation between serum cholinesterase levels and symptomatology was absent in some patients but present in the majority. Cholinesterase inhibition may not be the only mechanism by which organic phosphorus compounds cause poisoning.
\end{abstract}

Since organic phosphorus compounds were first used as insecticides in agriculture many reports and reviews have been published on poisoning by these compounds (e.g., Report of the Council on Pharmacy and Chemistry, 1950; Barnes and Davies, 1951; Namba and Hiraki, 1958; Barnes, 1959; and Quinby, 1964).

In Egypt, O,O-dimethyl S-ethylthioethyl phosphorothiolate (Meta-isosystox, Bayer) has been widely sprayed in early growing cotton fields to control thrips. In the Beni-Suef region, 673 spraymen were notified as poisoned by Meta-isosystox, including three deaths about one week after the programme of spraying had begun. In the present study estimations were made of serum cholinesterase (ChE) in some workers while they were showing toxic manifestations, and in an attempt to correlate the level of serum ChE with the degree of intoxication these patients were followed up until they had recovered. The only cases reported are those whose serum ChE was examined. The others had either recovered or were not available at the time of this test. Control individuals living in the same villages but not exposed to the spray were also examined.

\section{Methods}

Blood was collected by venipuncture in dry sterile tubes. Serum ChE was estimated by the method described by Reinhold, Tourigny, and Yonan (1953) on the same day except for a few samples, taken in the evening in emergency cases, which were kept in the refrigerator and estimated next day. Activity was measured as change in $p \mathrm{H}$ per hour at $25^{\circ} \mathrm{C}$.

A statistical analysis of the data was performed. Significance of means was measured by the $t$ test (Burn, Finney, and Goodwin, 1950).

\section{Subjects}

Cases of Poisoning.-Two hundred and sixty-seven samples of serum were taken from 121 men occupationally exposed to Meta-isosystox while spraying cotton fields, and 11 samples from five patients (three children and two young adults) accidentally exposed while near the spraying operations. The distribution of patients by age is shown in Table 1.

The first ChE estimation was carried out for each of 25 occupational patients and four accidental patients

\section{TABLE 1}

AGE DISTRIBUTION AMONG PATIENTS AND CONTROLS

\begin{tabular}{l|c|c|c}
\hline \multicolumn{1}{c|}{$\begin{array}{c}\text { Age } \\
\text { (years) }\end{array}$} & \multicolumn{2}{|c|}{ Patients } & Controls \\
\cline { 2 - 3 } & Occupational & Other & \\
\hline $6-12$ & - & 3 & 4 \\
$13-29$ & 63 & 2 & 24 \\
$30-49$ & 48 & - & 23 \\
50 and over & 10 & 5 & 67 \\
Total no. examined & 121 & 5 & 57 \\
\hline
\end{tabular}


within $24 \mathrm{hrs}$. of the onset of symptoms, for each of 60 patients who had had moderate or mild symptoms and signs for two days or more, and for 36 patients who had apparently already been cured. A re-estimation of ChE was carried out for most patients two to three times at various intervals up to 40 days from the onset. It was impracticable to collect more blood samples from the patients as they were inhabitants of distant villages.

Controls.-Serum samples were taken from 57 males, roughly matched for age with the cases of poisoning (Table 1) and from 20 females.

Exposure.-The cases of poisoning were all spraymen. None was engaged in mixing the chemicals, presumably because strict precautions were taken during mixing. The workmen were temporarily employed. They worked $8 \mathrm{hrs}$./day, and symptoms and signs of toxicity occurred after one to 18 days of exposure with a mean time of three days. Some patients were affected while still in the field, others not until they went home. None was exposed again to Meta-isosystox after the onset of symptoms.

They applied Meta-isosystox at a rate of 0.51 . of concentrate in 4001 . of spray per feddan (about 4,200 sq. m.). Most used hand-operated knapsack sprayers. The connexions with the spray-booms could be a source of leaks. The workmen were sometimes liable to contaminate their skin and clothes with the insecticide emulsion while refilling the spray tanks. A few of the patients examined used high-pressure motor-powered sprayers each with a large tank connected with a long hose to a multi-nozzled spray-boom. The spray was directed downwards and forwards towards the plants and down the wind to avoid spray falling back onto the operators.

Workmen washed exposed parts of their bodies with soap and water after spraying. However, washing was unsatisfactory. One cannot be sure that they bathed daily at home. Although some patients attended the hospitals during or after spraying with their working clothes on, it was customary to take off working clothes at the end of the working day, so it was unlikely that affected workmen had slept in their working clothes. One cannot decide whether the workmen had their clothes washed each time before re-use. Not all workers used protective clothing and masks.

The accidentally poisoned patients were three children and two young adults. Three were exposed for short times to vapours or mist in recently sprayed fields, one to accidental contamination of the skin, and another ate contaminated food. All patients were treated in hospital after the onset of symptoms until they improved clinically.

\section{Symptomatology}

The clinical picture as seen on estimating serum $\mathrm{ChE}$ for the first time is shown in Table 2. Signs and symptoms were usually improved by atropine, but they recurred in some patients on cessation of treatment. ChE re-activating agents such as 2-PAM (pyridine aldoxime methylchloride) and P2S (the methanesulphonate) were not available. Their use might well have shortened treatment.

TABLE 2

TOXIC MANIFESTATIONS OF META-ISOSYSTOX IN 121 OCCUPATIONALLY POISONED PATIENTS AS SEEN AT THE FIRST EXAMINATION OF SERUM CHOLINESTERASE

\begin{tabular}{|c|c|c|}
\hline Toxic Manifestations & No. & $\begin{array}{l}\% \text { of } \\
\text { Total }\end{array}$ \\
\hline $\begin{array}{l}\text { Gastrointestinal manifestations: } \\
\text { abdominal colic, } \uparrow \text { nausea,* vomiting, }{ }^{*} \text { diarrhoea, }{ }^{*} \\
\text { dyspepsia } \dagger\end{array}$ & 70 & 58 \\
\hline $\begin{array}{l}\text { Dizziness } \dagger \\
\text { Vague symptoms: }\end{array}$ & 28 & 23 \\
\hline general weakness, $\uparrow$ fatigue $\dagger$ & 23 & 19 \\
\hline $\begin{array}{l}\text { Respiratory manifestations } \dagger \\
\text { Headache } \dagger\end{array}$ & $\begin{array}{l}19 \\
19\end{array}$ & $\begin{array}{l}16 \\
16\end{array}$ \\
\hline $\begin{array}{l}\text { Secretory hyperactivity }{ }^{*} \\
\text { sweating, salivation, lacrymation }\end{array}$ & 15 & 12 \\
\hline $\begin{array}{l}\text { Tremors of outstretched hands, } \uparrow \text { intentional tremors, } \dagger \\
\text { ataxiat }\end{array}$ & 5 & \\
\hline Exaggerated superficial and deep reflexes* & 7 & \\
\hline Hiccough $\dagger$ & 3 & $\begin{array}{l}2.5 \\
2.5\end{array}$ \\
\hline $\begin{array}{l}\text { Muscular fasciculations* } \\
\text { Apparently cured }\end{array}$ & $\begin{array}{r}3 \\
36\end{array}$ & 30 \\
\hline
\end{tabular}

*Only in early stage; tpersistent for some days more.

TABLE 3

ACCIDENTALLY EXPOSED PATIENTS

\begin{tabular}{|c|c|c|c|c|c|c|c|c|}
\hline \multirow{2}{*}{ Patient } & \multirow{2}{*}{ Age } & \multirow{2}{*}{ Sex } & \multirow{2}{*}{ Mode and Duration of Exposure } & \multirow{2}{*}{ Predominant Symptoms and Signs* } & \multicolumn{4}{|c|}{$\begin{array}{l}\text { Serum ChE Levels } \\
(\Delta p \mathrm{H} / \text { hour })\end{array}$} \\
\hline & & & & & $\begin{array}{c}1 \\
\text { day }\end{array}$ & $\begin{array}{l}2,3 \\
\text { days }\end{array}$ & $\begin{array}{l}\text { 4-10 } \\
\text { days }\end{array}$ & $\begin{array}{l}11-20 \\
\text { days }\end{array}$ \\
\hline A.H.M. & 6 & $\mathbf{M}$ & Inhalation for a few minutes & $\begin{array}{l}\text { Drowsiness, vomiting, and abdominal } \\
\text { colic }\end{array}$ & $\begin{array}{c}0.81 \\
(1)\end{array}$ & $\begin{array}{c}0.89 \\
(2)\end{array}$ & $\begin{array}{c}0 \cdot 86 \\
(4)\end{array}$ & \\
\hline M.H.M. & 10 & $\mathbf{M}$ & Inhalation for a few minutes & $\begin{array}{l}\text { Drowsiness, vomiting, and abdominal } \\
\text { colic }\end{array}$ & $\begin{array}{c}0.83 \\
(1)\end{array}$ & $\begin{array}{c}0 \cdot 89 \\
(2)\end{array}$ & $\begin{array}{c}0.87 \\
(4)\end{array}$ & \\
\hline F.G.A. & 12 & $\mathbf{F}$ & Ingestion of contaminated food & Vomiting, diarrhoea, and drowsiness & $\begin{array}{c}0.53 \\
(1)\end{array}$ & & $\begin{array}{c}0.95 \\
(9)\end{array}$ & \\
\hline F.O.M. & 14 & $\mathbf{F}$ & Inhalation for a few minutes & $\begin{array}{l}\text { Apparently cured when seen on eleventh } \\
\text { day }\end{array}$ & & & & $\begin{array}{l}0.91 \\
(11) \\
1.04 \\
(13)\end{array}$ \\
\hline H.A.A. & 23 & $\mathbf{M}$ & $\begin{array}{l}\text { Skin contamination and inhalation while } \\
\text { repairing motor sprayer }\end{array}$ & $\begin{array}{l}\text { Dyspnoea, dizziness, coma for some } \\
\text { time, and vomiting }\end{array}$ & $\begin{array}{c}0.92 \\
(1)\end{array}$ & & & \\
\hline
\end{tabular}

* Symptoms and signs are described as found on the day of the first serum ChE estimation. All represented patients improved.

( ) no. of days since onset of poisoning. 
Some patients still complained of symptoms a week after onset. The condition was improved in all patients on subsequent examinations.

The cases of non-occupational (accidental) poisoning were apparently caused by very slight exposure. The case histories are therefore given below. The symptoms, signs, and $\mathrm{ChE}$ levels are summarized in Table 3.

\section{Case Histories}

Cases 1 and 2.-A.H.M., a boy aged 6 yrs., and M.H.M., a boy aged 10 yrs., were brothers and were brought to hospital in the evening of April 12, 1964 by their father who worked as a sprayman using a knapsack type sprayer. It was a hot day, with a maximum shade temperature of $35.9{ }^{\circ} \mathrm{C}$. The temperature was higher in the open field under direct sunlight.

The father stated that his children were walking beside the field while waiting for him at the end of the working day. Spraying was still going on when they fell to the ground unconscious for a few minutes. When aroused they vomited and complained of abdominal colic. They were immediately brought to the hospital. When first seen they were drowsy and complained of abdominal colic. They were given atropine immediately and this improved their condition. Blood samples for $\mathrm{ChE}$ estimation were taken about four hours after the onset of acute symptoms, put in the refrigerator and examined next day. The serum was clear and no haemolysis was noted. No treatment was required next day. Other conditions were excluded by clinical examination, and their temperatures were normal.

Circumstantial evidence favoured poisoning by Metaisosystox, although serum ChE estimated the following day was within normal limits. Their father was still wearing his working clothes, which were contaminated by the insecticide, and he said that some spray solution had been poured on them. His clothes were removed immediately and he washed himself. He complained of no symptoms. He denied that his children had played with tanks or empty containers.

Case 3.-F.G.A., a girl aged 12 yrs., ate beans while in the field during spraying, suffered vomiting and abdominal colic shortly after, and was admitted to hospital. When a blood sample was taken for serum ChE examination one day after the onset of symptoms her general condition was bad. There was drowsiness, vomiting, diarrhoea, generalized abdominal colic, and dehydration. The patient was put under strict supervision and received atropine, parenteral fluids, and antibiotics. Her chest was clear. Other conditions such as appendicitis and dysentery were excluded. Her condition improved within a few days. The ChE was 0.53 (low) on the first day and 0.95 on the ninth day.

Case 4.-F.O.M., a girl aged 14 yrs., gave a history of inhaling spray vapours. She had nothing to do with mixing or spraying. She complained of dizziness, headache, and abdominal colic, attended the hospital while suffering from symptoms, and improved rapidly on treatment. Her ChE levels were normal on the eleventh and thirteenth days.
Case 5.-H.A.A., a man aged 23 yrs., worked as a motor operator. He was not concerned with mixing or spraying. He was only affected after 37 days of work. He stated that, while he was repairing the motor, spray solution splashed on him and wetted his skin, and he inhaled its vapours. He complained of dyspnoea and dizziness, and 'felt nothing afterwards'. When he became conscious he vomited several times and was brought to hospital where he received treatment. When a blood sample was taken for serum ChE estimation about eight hours after the onset of symptoms he still complained of dizziness, a heavy sensation in the epigastrium, and mild abdominal colic. On examination he had no particular signs (except pre-existing hepatosplenomegaly). The reflexes were normal. Serum ChE was examined the same night and was 0.92 (normal). He was discharged from hospital the next day with no symptoms.

Samples from two occupational cases showing severe symptoms and signs were taken and examined on the same night. Their ChE levels were 0.23 and 0.4 , i.e., markedly low.

\section{Results}

It was noticed that the number of cases of poisoning increased on hot days. This might have been due partly to increased volatility which enhanced absorption by inhalation, and to the increase in blood flow through the skin brought about by high environmental temperatures, which therefore increased the rate of skin absorption. The volatility of Meta-isosystox increases from $4.5 \mathrm{mg} . / \mathrm{m}^{3}$ air at $20^{\circ} \mathrm{C}$. to $12.4 \mathrm{mg} . / \mathrm{m}^{3}$ at $30^{\circ} \mathrm{C}$. and $34 \mathrm{mg} . / \mathrm{m} .{ }^{3}$ air at $40^{\circ} \mathrm{C}$. (Schrader, 1963).

Serum Cholinesterase Levels.-The results are shown in Tables 4, 5, and 6 and in Figure 1. In occupationally poisoned patients the general picture was one of marked initial fall followed by a rise after about 30 days to above normal.

Table 6 shows the number of patients in whom the ChE levels were more than $20 \%$ above or below normal, these being regarded as significant according to the criterion suggested by Callaway, Davies, and Rutland (1951). (They studied plasma ChE, but this is the same as serum ChE (Adams and Thompson, 1948).) On this criterion most showed falls in the first 10 days, and most showed a significant rise above normal 30 to 40 days after the onset:

Non-occupationally exposed patients had received a dose in a very short time. In them the ChE levels were not appreciably reduced (Tables 3 and 4), and there was no relation between the severity of the symptoms and the ChE levels. These patients recovered more rapidly.

\section{Discussion}

Taylor (1963) found that plasma (serum) ChE was 
TABLE 4

SERUM CHOLINESTERASE LEVELS IN CONTROLS AND IN PATIENTS AFTER VARIOUS INTERVALS SINCE ONSET OF TOXIC MANIFESTATIONS

\begin{tabular}{|c|c|c|c|c|c|c|c|c|c|c|c|}
\hline & \multirow{3}{*}{$\begin{array}{l}\text { Con- } \\
\text { trols }\end{array}$} & \multicolumn{6}{|c|}{ Occupationally Poisoned Patients } & \multicolumn{4}{|c|}{ Other Patients $\dagger$} \\
\hline & & \multicolumn{6}{|c|}{ Days } & \multicolumn{4}{|c|}{ Days } \\
\hline & & 1 & 2,3 & 4-10 & $11-20$ & $21-30$ & $31-40$ & 1 & 2,3 & 4-10 & $11-20$ \\
\hline $\begin{array}{l}\text { No. examined } \\
\text { Mean } \Delta p H / h o u r \\
\text { Standard deviation } \pm \\
\text { Standard error } \pm \\
\text { Significance of } \\
\text { difference be- } \\
\text { tween patients } \\
\text { and controls }\end{array}$ & $\begin{array}{l}53 \\
0.788 \\
0.21 \\
0.029\end{array}$ & $\begin{array}{l}25 \\
0.287 \\
0.17 \\
0.034 \\
10.46 \\
<0.001\end{array}$ & $\begin{array}{l}15 \\
0.286 \\
0 \cdot 14 \\
0.035 \\
\\
8.68 \\
<0.001\end{array}$ & $\begin{array}{l}25 \\
0.460 \\
0.18 \\
0.037 \\
6.70 \\
<0.001\end{array}$ & $\begin{array}{l}92 \\
0.649 \\
0.20 \\
0.020 \\
4.01 \\
<0.001\end{array}$ & $\begin{array}{l}38 \\
0.857 \\
0.16 \\
0.026 \\
1.69 \\
<0.1\end{array}$ & $\begin{array}{l}22 \\
1.033 \\
0.23 \\
0.048 \\
4.50 \\
<0.001\end{array}$ & $\begin{array}{l}4 \\
0.773 \\
0.26 \\
0.13\end{array}$ & $\begin{array}{l}2 \\
0 \cdot 890 \\
0 \\
0\end{array}$ & $\begin{array}{l}3 \\
0.893 \\
0.049 \\
0.029\end{array}$ & $1^{1} .975^{*}$ \\
\hline
\end{tabular}

* Mean of two samples on different days. +Only some calculations are given because the numbers were small.

TABLE 5

SERUM CHOLINESTERASE LEVELS OF SUBJECTS NOT EXPOSED TO SPRAY

\begin{tabular}{c|c|c|c|c|c}
\hline Sex & $\begin{array}{c}\text { Age } \\
\text { (years) }\end{array}$ & No. & $\begin{array}{c}\text { Mean } \\
\Delta p \mathrm{H} / \\
\text { hour }\end{array}$ & S.D. & S.E. \\
\hline Male & $6-12$ & 4 & $\mathbf{0 . 8 4}$ & $\pm 0 \cdot 16$ & \pm 0.079 \\
& $13-29$ & 24 & $0 \cdot 805$ & $\pm 0 \cdot 18$ & \pm 0.037 \\
& $30-49$ & 23 & $0 \cdot 761$ & \pm 0.25 & \pm 0.052 \\
& $50-65$ & 6 & 0.823 & \pm 0.14 & \pm 0.059 \\
& $\begin{array}{c}\text { Total } \\
13-65\end{array}$ & 57 & 0.791 & \pm 0.20 & \pm 0.027 \\
& Considered & 53 & 0.788 & \pm 0.21 & \pm 0.029 \\
as controls & & & & \\
\hline Female & $10-70$ & 20 & 0.88 & \pm 0.21 & \pm 0.048 \\
\hline
\end{tabular}

S.D. = standard deviation; S.E. $=$ standard error.

definitely depressed in humans by fenthion (which is a dimethyl phosphate ester) when erythrocyte $\mathrm{ChE}$ was not and he concluded that plasma ChE afforded a more sensitive index of absorption of fenthion. Since Meta-isosystox is also a dimethyl phosphate ester it may be assumed that serum $\mathrm{ChE}$, which is identical to plasma ChE, should be a more sensitive index of absorption of Meta-isosystox. However, serum ChE was not usually more sensitive than erythrocyte ChE for dimethyl phosphate esters in vitro (Aldridge, 1953).

Controls of the same sex, age, and occupation (farming) and living under the same environmental conditions were examined for two reasons: (1) Other factors might have contributed to a deviation of serum ChE from normal, e.g., low levels were observed in cases of malnutrition (McCance, 1950) and liver disease (Antopol, Schifrin, and Tuchman, 1938). Our patients were farm workers and were prone to tropical diseases, especially bilharziasis. (2) The initial levels in patients before exposure to the insecticide were not known.

Allowance must also be made for fluctuations in

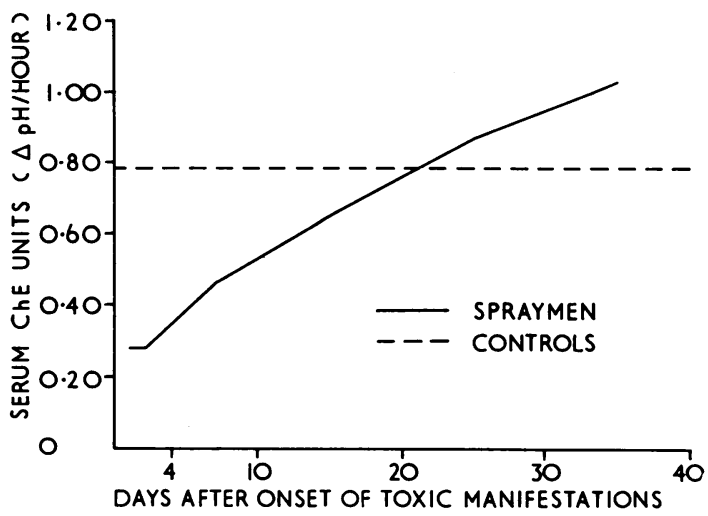

FIG. 1.-Serum $\mathrm{ChE}$ levels in spraymen and controls.

TABLE 6

CHANGES OF SERUM CHOLINESTERASE LEVELS IN PATIENTS OCCUPATIONALLY POISONED BY META-ISOSYSTOX

\begin{tabular}{|c|c|c|c|c|c|c|c|c|c|c|c|c|c|c|c|}
\hline \multirow{3}{*}{$\begin{array}{l}\text { Time since Onset } \\
\text { of Poisoning } \\
\text { (days) }\end{array}$} & \multicolumn{11}{|c|}{ No. of Patients } & \multirow{3}{*}{$\begin{array}{l}\text { Total No. } \\
\text { Examined }\end{array}$} & \multicolumn{3}{|c|}{$\begin{array}{l}\text { No. of Patients as } \\
\text { Percentage of Total }\end{array}$} \\
\hline & \multicolumn{5}{|c|}{$\begin{array}{l}\text { With Fall in Serum ChE below } \\
\text { Controls }\end{array}$} & \multirow{2}{*}{$\begin{array}{c}\text { With no } \\
\text { Change } \\
\pm 19.9 \% \\
\text { of Controls }\end{array}$} & \multicolumn{5}{|c|}{$\begin{array}{l}\text { With Rise in Serum ChE above } \\
\text { Controls }\end{array}$} & & \multirow{2}{*}{$\begin{array}{l}\text { With } \\
\text { Fall }\end{array}$} & \multirow{2}{*}{$\begin{array}{c}\text { With } \\
\text { no } \\
\text { Ch'ge }\end{array}$} & \multirow{2}{*}{$\begin{array}{l}\text { With } \\
\text { Rise }\end{array}$} \\
\hline & $-20 \%$ & $-40 \%$ & $-60 \%$ & $-80 \%$ & Total & & $+20 \%$ & $+40 \%$ & $\%+60 \%$ & $+80 \%$ & Total & & & & \\
\hline $\begin{array}{l}1 \\
2-3 \\
4-10 \\
11-20 \\
21-30 \\
31-40\end{array}$ & $\begin{array}{r}1 \\
2 \\
6 \\
26 \\
4 \\
1 \\
1\end{array}$ & $\begin{array}{r}5 \\
4 \\
10 \\
10 \\
=\end{array}$ & $\begin{array}{r}13 \\
7 \\
5 \\
7 \\
- \\
\end{array}$ & $\begin{array}{l}5 \\
2 \\
1 \\
= \\
=\end{array}$ & $\begin{array}{r}24 \\
15 \\
22 \\
43 \\
4 \\
1\end{array}$ & $\begin{array}{r}1 \\
3 \\
44 \\
19 \\
7\end{array}$ & $\begin{array}{c}\overline{-} \\
3 \\
14 \\
7\end{array}$ & $\begin{array}{l}\bar{Z} \\
\overline{2} \\
\frac{1}{3}\end{array}$ & $\begin{array}{l}\bar{z} \\
\bar{z}\end{array}$ & $\begin{array}{l}\bar{Z} \\
\bar{z}\end{array}$ & $\begin{array}{l}\bar{Z} \\
\overline{5} \\
15 \\
14\end{array}$ & $\begin{array}{l}25 \\
15 \\
25 \\
92 \\
38 \\
22\end{array}$ & $\begin{array}{c}96 \\
100 \\
88 \\
46 \cdot 7 \\
10.5 \\
4.5\end{array}$ & $\begin{array}{l}\frac{4}{12} \\
47 \cdot 8 \\
50 \\
31 \cdot 8\end{array}$ & $\begin{array}{l}\bar{Z} \\
\bar{Z} \\
59.4 \\
63.5 \\
63.6\end{array}$ \\
\hline
\end{tabular}


each individual, which may amount to $10 \%$ to $15 \%$ (Callaway et al., 1951).

On comparing female controls with male controls, females were found to have a higher average ChE level than males. This is in contrast to the results obtained by Reinhold et al. (1953), and by Rider, Hodges, Swader, and Wiggins (1957), who found that females had lower levels than males, and Shakir, Saif, and Abdel-Fattah (1963) who found no significant difference with regard to age or sex in healthy Egyptians. The difference is probably due to the fact that males are more affected by bilharziasis than females in Egypt (Mousa, 1962). It has been shown that bilharziasis decreases serum ChE activity, probably by affecting the liver (Shakir, Saif, and Abdel-Fattah, 1964).

The environmental conditions under which this investigation was carried out might in part have contributed to an enhancement of the toxicity of the compound:

(1) Spraying was performed in open fields under direct sunlight. This may tend to raise the temperature of the spray solution inside the tanks.

(2) In such an extensive programme stocks of the insecticide must have been stored for some time.

Heath and Vandekar (1957) found that Metaisosystox gave more toxic derivatives on heating, storage or in water. The main products were nontoxic ions, but self-alkylation gave the methylsulphonium derivative (O,O-dimethyl S-ethylsulphonioethylmethyl phosphorothiolate), which is a very toxic compound (i.v. $\mathrm{LD}_{50}$ in rats $0.062 \mathrm{mg}$. $/ \mathrm{kg}$. compared with i.v. $\mathrm{LD}_{50}$ in rats $64.6 \mathrm{mg} . / \mathrm{kg}$. for Meta-isosystox). Conversion into the alkylsulphonium drivative far outweighed in its effect conversion into inert ionic products. They found that storage of a sample of Meta-isosystox for two years increased its intravenous toxicity 100 times. The oral toxicity was not appreciably affected, but it is possible that spray may be absorbed through the lungs more readily.

In addition to the usual symptoms and signs of organic phosphorus poisoning due to stimulation of the post-ganglionic nerves, preganglionic nerves, somatic motor nerves, and the central nervous system (Grob, 1950; Barnes, Hayes, and Kay, 1957), the following manifestations were noticed:

(1) Extrapyramidal manifestations, e.g., intentional tremors, ataxic gait, incoordination of movements, and parkinsonism. These might be due to central imbalance in favour of cholinergic mechanisms. All cases improved and no ataxia persisted.

(2) Hiccough, which persisted for some days. It was probably of central origin. Kidney function tests were not done, but the amount of urine was normal.
(3) After the acute symptoms had subsided, headache, dizziness and muscular weakness, especially in the lower limbs, persisted for varying periods.

Serum ChE levels in the early stage of poisoning in occupationally exposed patients were reduced as expected. Reduction was more marked in patients who were exposed for longer periods. In most patients toxic manifestations were proportional to the reduction of serum ChE levels. This indicates that the symptoms were at least partly due to cholinesterase inhibition. However, one should not ignore the fact that organic phosphorus compounds interfere with many other enzyme systems (Aldridge, 1954; Mounter, Shipley, and Mounter, 1963). Friborská-Waelschová (1957) suggested that the poisonous action of organic phosphorus compounds could not be explained solely as an inhibition of cholinesterases, and that neurological disturbances in patients poisoned by organophosphorus compounds were the result of the stimulant action of organic phosphates on sympathetic ganglia and cerebral centres.

Some occupational patients had low serum $\mathrm{ChE}$ levels although they were apparently cured. This suggests that ChE activity by itself may not be the only cause of the symptoms and signs of poisoning, or that the body might adapt itself to the disturbance caused by organic phosphorus compounds.

Reduction of serum $\mathrm{ChE}$ was not evident in patients who were accidentally exposed to the insecticide for a short time. The symptoms in this group were severe and disproportionate to the level of serum ChE. It is possible that serum $\mathrm{ChE}$ was reversibly inhibited and was reactivated before examination, since there was no prolonged exposure to the inhibitors. Vandekar and Heath (1957) have shown that non-persistent inhibitors, such as O,O-dimethyl S-ethylsulphonioethyl-methyl phosphorothiolate, cause symptoms of short duration in animals, and the formation of this compound from Meta-isosystox is enhanced in hot weather. On the other hand, they found that when dimethyl phosphate esters were absorbed slowly the biochemical lesion was more serious although the $\mathrm{LD}_{50}$ was much higher. Irreversible inhibition resulted from prolonged exposure. Symptoms of mild poisoning may, however, be found in persons with normal cholinesterase levels (Barnes et al., 1957).

After the gradual recovery of serum ChE a significant rise over the mean of controls was noticed in the majority of patients examined more than one month after the onset of poisoning (Tables 4 and 6). This rebound phenomenon may be a compensatory protective mechanism. The rise in the serum $\mathrm{ChE}$ activity could be due to new formation of this enzyme from the liver as well as to the re-activation 
of the already inhibited enzyme. In a survey of organophosphorus insecticides made by Elliott and Barnes (1963) in Nigeria, the data showed that after 42 days of spraying fenthion, blood cholinesterase levels were raised in the majority of persons examined. This protective mechanism may explain the observation made by Hayes, Dixon, Batchelor, and Upholt (1957) that poisoning from longcontinued exposure was never serious, and again suggests that some degree of tolerance may develop in persons exposed to organic phosphorus compounds for long periods.

My thanks are due to Dr. H. S. Youssef, the GeneralDirector of Laboratories of the Ministry of Health, and to Dr. N. A. Awad, the Director of Biological Products Control Section, for suggesting this study and for their generous help. I appreciate the efforts and facilities offered by Dr. A. Abou-Hashish, the General-Director of Health in Beni-Suef, Dr. M. I. Hegab, the AssistantDirector, Dr. H. Baseem, the Director of Beni-Suef General Hospital, and the staff of the same hospital, and the Directors and staff of the Central Hospitals of Ihnasia El-Madinah, Baush and Smosta.

I wish to thank Dr. H. Ghaleb for his valuable comments, and Dr. K. Madkour and Dr. M. A. Ezz El-Arab for help with the statistical analysis.
REFERENCES

Adams, D. H., and Thompson, R. H. S. (1948). Biochem. J., 42, 170. Aldridge, W. N. (1953). Ibid., 53, 62.

Aldridge, (1954). Chem. Industr., p. 473.

Antopol, W., Schifrin, A., and Tuchman, L. (1938). Proc. Soc. exp. Biol. Med. (N.Y.), 38, 363.

Barnes, J. M. (1959). Bull. Hyg. (Lond.), 34, 1205.

and Davies, D. R. (1951). Brit. med. J., 2, 816.

, Hayes, W. J., and Kay, K. (1957). Bull. Wld Hlth Org., 16, 41.

Burn, J. H., Finney, D. J., and Goodwin, L. G. (1950). Biological Standardization, 2nd ed. Oxford University Press, London.

Callaway, S., Davies, D. R., and Rutland, J. P. (1951). Brit. med.J., 2,812 .

Elliott, R., and Barnes, J. M. (1963). Bull. Wld Hlth Org., 28, 35.

Friborská-Waelschová, A. (1957). Arch. Gewerbepath. Gewerbehyg., 16, 63. (As quoted by Bull. Hyg. (Lond.), 33, 368. 1958.)

Grob, D. (1950). J.Amer. med. Ass., 144, 105.

Hayes, W. J., Jr., Dixon, E. M., Batchelor, G. S., and Upholt, W. M. (1957). Pub. Hlth Rep. (Wash.), 72, 787. (As quoted by Bull. Hyg. (Lond.), 33, 55. 1958.)

Heath, D. F., and Vandekar, M. (1957). Biochem. J., 67, 187.

McCance, R. A. (1950). Proc. roy. Soc. Med., 43, 272.

Mounter, L. A., Shipley, B. A., and Mounter, M. E. (1963). J. biol. Chem. 238, 1979.

Mousa, A. H. (1962). In Ciba Foundation Symposium: Bilharziasis. P. 1. Churchill, London.

Namba, T., and Hiraki, K. (1958). J. Amer. med. Ass., 166, 1834.

Quinby, G. E. (1964). Ibid., 187, 202.

Reinhold, J. G., Tourigny, L. G., and Yonan, V. L. (1953). Amer. J. clin. Path., 23, 645.

Report of the Council on Pharmacy and Chemistry (1950). J. Amer.

Rider, J. A., Hodges, J. L., Swader, J., and Wiggins, A. D. (1957). J. Lab. clin. Med., 50, 376.

Schrader, G. (1963). Die Entwicklung neuer insektizider Phosphorsäure-Ester, 3rd ed., p. 406.

Shakir, M. H., Saif, M., and Abdel-Fattah, F. (1963). J. Egypt. med. Ass., 46, 388.

(1964), Ibid. 47, 122.

Taylor, A. (1963). Bull. Wld Hlth Org., 29, 213.

Vandekar, M., and Heath, D. F. (1957). Biochem. J., 67, 202.

\section{THE APRIL (1965) ISSUE}

The April (1965) issue contains the following papers:-

Effect of Quality of Chest Radiographs on the Categorization of Coalworkers' Pneumoconiosis. N. G. Pearson, J. R. Ashford, D. C. Morgan, R. S. H. Pasqual, and S. Rae

Mortality in Coalworkers' Pneumoconiosis Related to Lung Function: A Prospective Study. P. D. OldhAM and C. E. Rossiter

Byssinosis in Cardroom Workers in Swedish Cotton Mills. L. Belin, A. Bouhuys, W. Hoekstra, M.-B. Johansson, S.-E. Lindell, and J. PoOL

Ventilatory Capacity in Flax Workers in Northern Ireland. G. C. R. Carey, J. D. Merrett, P. C. Elwood, J. Pemberton, and I. R. McAulay

Changes in Ventilatory Capacity in a Group of Flax Workers in Northern Ireland. G. C. R. CAREY and J. D. MerRetT

Air Pollution in a City Street. R. E. Waller, B. T. Commins, and P. J. Lawther

A Sensitive Method for the Determination of Carboxyhaemoglobin in a Finger Prick Sample of Blood. B. T. COMmins and P. J. LAWTHER

Tennis Elbow in Industry. A. SincLaIR

Respiratory Symptoms and Smoking Habits of Senior Industrial Staff. Susan H. Meadows, C. H. Wood, and R. S. F. SCHILling

Pneumoconiosis in a Coalworker from Ceylon. G. H. Cooray and P. R. Wikramanayake

Asthma Caused by the Grain Weevil. A. W. Frankland and J. A. LunN

Book Reviews

A number of copies are still available and may be obtained trom the Publishing Manager, British Medical Association, Tavistock Square, W.C.1, price 18s. $6 d$. 